\title{
Ecotourism Development Strategy of Pelawan Forest in Central Bangka, Bangka Belitung
}

\author{
Henri $^{1,3 *}$, Luchman Hakim², Jati Batoro ${ }^{2}$ \\ ${ }^{1}$ Master Program of Biology, Faculty of Mathematics and Natural Sciences, University of Brawijaya, Malang, Indonesia \\ 2Department of Biology, Faculty of Mathematics and Natural Sciences, University of Brawijaya, Malang, Indonesia \\ ${ }^{3}$ Department of Biology, University of Bangka Belitung, Bangka, Indonesia
}

\begin{abstract}
Ecotourism has a very important role in increasing the community income, cultural preservation, and environmental conservation efforts at a tourist attraction. This study aims to create the ecotourism development strategy in Pelawan Forest by involving local communities. Data collection techniques in this study using distributing questionnaires to tourists. Data were analyzed using a Likert scale analysis, IFAS/EFAS analysis, SWOT analysis to formulate ecotourism development strategy viewed factors internal and external as well Grand strategy matrix. The results research using Likert scale showed that the various attractions i.e. the area that is still awake, unique flora and fauna, the existence of alternative tourism can become a tourist attraction potential. Meanwhile, the potential demand for tourism is mostly students and employees. Ecotourism development of Pelawan Forest based on SWOT analysis can be offered by involving local communities and stakeholders in support of sustainable tourism. The position of the Grand Strategy Matrix lies in the ordinate quadrant 2, is characterized by a weak competitive position in fast growing market. Therefore, it is necessary to take counteractive action so that the ability to compete effectively is stronger and can find its space in a more competitive environment, thus becoming a sustainable ecotourism.
\end{abstract}

Keywords: Development strategy, ecotourism, Pelawan Forest.

\section{INTRODUCTION}

Recently, tourism has been considered as one of the new economic machines in Bangka Belitung Province. Statistical data shows that tourism grows significantly and the economic impact of tourism has been reported significant. In 2011, Bangka Belitung has visited by 1,495 international tourist and 191,200 domestic tourists. In 2012, a number of international tourists were recorded about 1,864 while a domestic tourist was recorded about 221,747. The continuous increase was recorded in 2013, where international tourist arrival was about 2,035 and domestic tourist as recorded about 236,370. In 2015, a number of international tourists were 3,498 and a domestic tourist was about 301,938 [1].

The use of natural resources for tourism development has been identified significant. Scholar points out that natural resources, especially in tropical countries, is crucial to attracting tourist. The abundance and luxuries tropical forest is a magnet for tourism development. The mutual relationship between tourism and conservation has been widely

\footnotetext{
* Correspondence address:

Henri

Email : henry_4ch74@yahoo.com

Address : Department of Biology, University of Brawijaya Veteran, Malang, 65145
}

discussed and conclude that tourism and conservation can be in harmony $[2,3]$.

The recent development of tourism in Bangka Belitung has also the significant impact on forest conservation. Forest abundance in Bangka Belitung a there is opportunities for tourism in the forest area. Tourism, if properly managed, contributes to the forest conservation. As many developing countries, however, the uses of the forest as tourism destination related to the local community existence, in which their contribution to sustainable and successful of forest-based tourism is crucial $[4,5]$. Another issue of tourism development in Bangka Belitung was related to the tourism satisfaction and conservation agenda, in which tourism learn about biodiversity. Therefore, assessing the quality of destination was important.

The sustainable tourism in Pelawan Forest need a strategy to increase tourism benefit to biodiversity conservation and local community development. It is also crucial in ensure economic benefit derived from tourism, while tourism satisfaction as achieved. As far, few studies were implemented in Pelawan forest. The aims of the research are to analyses the potentiality of the Pelawan Forest as a tourism destination. 


\section{RESEARCH METHOD}

\section{Study Area}

The research was conducted at Pelawan Forest, Namang Village, Central Bangka District, Bangka Belitung. The Pelawan Forest has a total area are 47.4 ha has been used as a Biodiversity Park of
Pelawan Forest in 2013. Geographically it is located on $106^{\circ} 11^{\prime} 00,19$ BT and $2^{\circ} 22^{\prime} 03,25$ LS (Fig. 1). Biodiversity Park of Pelawan Forest is included in category IV in the list of the United Nations (UN), with the main purpose to protect, conserve and restore species and habitats [6].

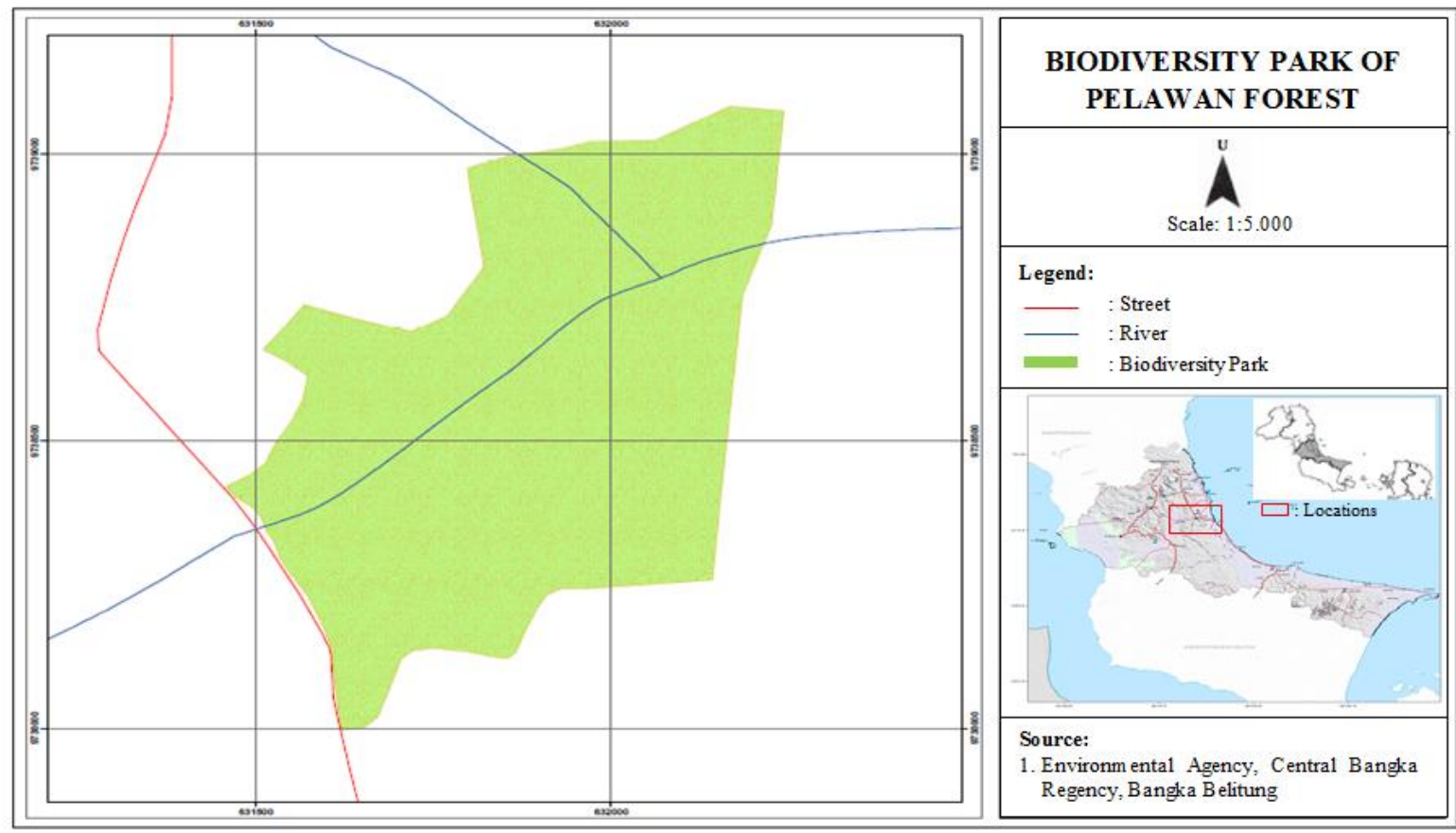

Figure 1. Map Biodiversity Park of Pelawan Forest and Research Sites

\section{Methods}

\section{Data Collection}

The source of this research data in the form of qualitative and quantitative data that can be calculated or processed using statistics to draw conclusions, such as weighted average and assessment of tourists on the development of ecotourism of Pelawan Forest. The data is taken by purposive sampling by using a sampling of 100 tourists who have visited Pelawan Forest. Visitors assessment on Pelawan Forest as tourism destination was perform through questionnaire assessment of five elements, including tourist perception to assess Pelawan Forest as ecotourism objects (five indicators of assessment), supporting elements of ecotourism attraction (seven indicators of assessment), facilities and infrastructure of attraction (seven indicators of assessment), efforts to promote the attractions (two assessment indicators) and assessment on services provided by the local people for the traveler (five indicators of assessment).

\section{Data Analysis}

The obtained data analysed by using SWOT analysis, comparing the internal and external factors in the form of IFAS (Internal Factor Analysis Summary) matrix and EFAS (External Factor Analysis Summary) matrix quantitatively. Each factor was given a value rating from 1 to 4 $(1=$ the underlying weakness; $2=$ minor weakness; 3 = sufficient strength; and $4=$ great strength). The final result can be determined by the amount of weight multiplied by the value [7].

The results of EFAS/IFAS matrix become coordinate points in the SWOT diagram. IFAS matrix, if the value is more than 2.5 showed that there was more strength than a weakness. This also applied to EFAS matrix, if the value was more than 2.5, it showed that more opportunities than threats [8]. In addition, the determination of performed SWOT analysis was to analyze the advantages and disadvantages of an ecotourism location as well as suggestions for improvement of ecotourism plan [9]. 


\section{RESULT AND DISCUSSION}

Tourist perspective on Tourism Program in Pelawan Forest

\section{Characteristics of Respondents}

Results of a survey conducted with a sample of 100 respondents consisting of 50 respondents of local communities Bangka Belitung and 50 respondents of outside Bangka Belitung areas including foreign countries. The general profile of respondents was presented in (Table 1).

The respondents' profile who visit Pelawan Forest similar with the market segment of ecotourism. According to The International Ecotourism Society (TIES), the profile is in accordance with ecotourism principles, such a positive impact and provide a memorable experience for visitors; build environmental and cultural awareness and provide direct benefits from the tourist revenue to conserve.

\begin{tabular}{|c|c|}
\hline Variable & Total (\%) \\
\hline \multicolumn{2}{|l|}{ Gender } \\
\hline Male & 58 \\
\hline Female & 42 \\
\hline \multicolumn{2}{|l|}{ Age } \\
\hline $18-25$ & 41 \\
\hline $26-35$ & 34 \\
\hline $36-45$ & 13 \\
\hline $46-65$ & 12 \\
\hline \multicolumn{2}{|l|}{ Education } \\
\hline Primary School & 1 \\
\hline Junior High School & 1 \\
\hline Senior High School & 16 \\
\hline Academy/College & 82 \\
\hline \multicolumn{2}{|l|}{ Work } \\
\hline Student & 26 \\
\hline Government Employees & 34 \\
\hline Private Employees & 26 \\
\hline Entrepreneur & 7 \\
\hline and Other & 7 \\
\hline \multicolumn{2}{|l|}{ Visit } \\
\hline 1-2 times & 82 \\
\hline 3-4 times & 8 \\
\hline$\geq 5$ times & 10 \\
\hline \multicolumn{2}{|l|}{ Income (Monthly) } \\
\hline$<$ Rp. 1.000 .0000 & 23 \\
\hline Rp. 1.100.000-Rp. 2.000.000 & 8 \\
\hline Rp. 2.100.000-Rp. 3.000.000 & 41 \\
\hline Rp. 3.100.000-Rp. 5.000.000 & 23 \\
\hline$>$ Rp. 5.000 .0000 & 3 \\
\hline
\end{tabular}

Source: Data analysis, 2017.

\section{Visitors perception}

The result of the analysis (Table 2), shows that Pelawan Forests is declared eligible and agree to be developed. The average value of the tourist's perception on each element of assessment, such as the tourist's perception on to the develop- ment of Pelawan Forest as ecotourism attractions (4.38). This is because the ecotourism object Pelawan Forest has implemented conservation efforts and community involvement in terms of management so we can say that it has an economic impact on local communities. The average value in each of the other aspects such as eco-tourism attraction (4.05), infrastructure (3.60), promotion (3.96) and the services offered by the local community (3.99).

This means that Pelawan Forest at this time can be used as one of the special tourist attraction of ecotourism that is supported with unique natural resources/unique that is not owned in other areas. In addition, various ecotourism attractions such as wild honey bee observation, observation of opponent mushrooms, bird watching tours, riding tours to culinary tourism. Based on the analysis of Likert analysis, it can be explained that the need for the improvement of supporting facilities and infrastructure and still very necessary to be promoted so that tourists from outside the Bangka Belitung region more familiar with this Pelawan Forest ecotourism. The role of local communities as ecotourism services is also an important concern for promoting the integration of conservation and sustainable development of Pelawan Forest.

\section{Ecotourism development strategy Internal factor analysis}

IFAS matrix presented in (Table 3), showed that there were 14 factors related to the strength and weaknesses. Opportunities weight value was between 0.05 and 0.07 with a score of effectiveness between 3 and 4 , while the weakness weighs between 0.06 and 0.12 with a score of the effectiveness of 1 and 3.

Thus, the total internal factor (2.70) is more than 2.5 which means more strength than a weakness. This is supported by the potential of flora and fauna is quite high, diversity of ecotourism attractions support and accessibility to the location of ecotourism objects that are strategic enough. Some fundamental issues remain a disadvantage in the development of Pelawan Forest ecotourism, the need for increased awareness of actors and managers as a service to promote awareness of conservation and the environment, in order to minimize the current weakness factor. The existing potential becomes the strength to see the weakness in supporting the development of Pelawan Forest by considering the concept of accessibility, 
power, and resilience that can be used as a way of sustainable management as an object of ecotourism [10].

\section{External factor analysis}

The external aspects of tourism development are developed using the EFAS (External Factor Analysis Summary) matrix shown in Table 4. There are 8 factors related to probability, with weights of 0.06 and 0.12 with scores of 3 and 4 .

The most important factors that become opportunities based on the highest weight is the development of special economic zones. Bangka Belitung tourism can attract the number of tourist visits, so it can affect the increase in local revenue with the development of sustainable tourism and help the local economy with the creation of employment.

While external factors Threat consisting of 3 factors with a weight of 0.09 and 0.17 in the range of scores 3 and 4 . The main factors that pose respectively include the existence of mass tourist support that can damage the habitat of flora and fauna, less favorable conditions for tourists if the icon/characteristic of this tour does not exist when visited and Lack of attention to the environmental impact of various development projects in the object of tours. Ultimately, the total value of external factor 3.11 is more than 2.5 which means that the odds are more of a threat.

The result of external factor analysis shows that the development of Pelawan forest ecotourism must consider its environment as a tourist object. The goal is to meet the elements of conservation of natural resources and benefits in a sustainable manner to support the improvement of the community and regional quality of life, as well as providing a pleasant experience for visiting tourists. Therefore, ecotourism development requires prudent decision making to minimize environmental impact [11].

Table 2. Traveler ratings to attraction in Pelawan Forest

\begin{tabular}{|c|c|c|c|}
\hline $\begin{array}{l}\text { Elements of } \\
\text { evaluation }\end{array}$ & $\begin{array}{l}\text { Assessment } \\
\text { indicators }\end{array}$ & $\begin{array}{c}\text { Value } \\
\text { perception }\end{array}$ & Information \\
\hline Ecotourism & Pelawan Forests is very potential and interesting to be attractions & 4.17 & Agree \\
\hline \multirow{3}{*}{ perception } & Pelawan Forests involve local communities in the management & 4.44 & Strongly agree \\
\hline & Pelawan Forests can provide economic benefits for the society & 4.48 & Strongly agree \\
\hline & Management and development is still applying local wisdom & 4.49 & Strongly agree \\
\hline \multirow{5}{*}{$\begin{array}{l}\text { Ecotourism } \\
\text { attraction }\end{array}$} & The existence of wild honey bees observation and fungus of Pelawan & 4.35 & Strongly agree \\
\hline & The development of night tourism, bee therapy, and bird watching & 3.86 & Agree \\
\hline & The development of alternative tourism such as culinary and agro-tourism & 3.79 & Agree \\
\hline & The development of camping ground area for camp activities & 3.89 & Agree \\
\hline & Pelawan Forest is made to be education/learning and research center & 4.28 & Strongly agree \\
\hline \multirow{4}{*}{ Infrastructure } & The need for the provision of homestay for tourists & 3.52 & Agree \\
\hline & Supporting facilities such as places of worship, restrooms and parking lots & 3.33 & Neither \\
\hline & Bridges in the region to help tourists enjoy the sights & 3.66 & Agree \\
\hline & Information center providing insight to recognize the tourism potential & 2.79 & Neither \\
\hline \multirow[t]{2}{*}{ Promotion } & $\begin{array}{l}\text { Promotion is performed with involvement of local communities and the } \\
\text { government }\end{array}$ & 4.15 & Agree \\
\hline & $\begin{array}{l}\text { Pelawan Forest Promotion through printed/online medias and tourism } \\
\text { events has often been performed }\end{array}$ & 3.77 & Agree \\
\hline \multirow[t]{3}{*}{ Services } & Local communities is friendly to tourists visiting & 4.27 & Strongly agree \\
\hline & Local communities seek to provide the needs of tourists visiting & 4.00 & Agree \\
\hline & Local communities are willing to guide for travelers & 3.93 & Agree \\
\hline
\end{tabular}

Source: Data analysis, 2017. 
Table 3. IFAS (Internal Factor Analysis) Summary

\begin{tabular}{|c|c|c|c|c|}
\hline \multirow{3}{*}{ No. } & \multirow{2}{*}{ Internal Factors } & \multicolumn{3}{|c|}{ Value } \\
\hline & & Weight & Rating & Score \\
\hline & (1) & (2) & (3) & $(4 *)$ \\
\hline \multicolumn{5}{|c|}{ Strength } \\
\hline 1. & The potential biodiversity of flora and fauna of Pelawan Forest is high & 0.07 & 4 & 0.28 \\
\hline 2. & Involvement of local communities in managing tourism objects & 0.06 & 4 & 0.24 \\
\hline 3. & The access road to tourism place is very easily passed/taken & 0.05 & 3 & 0.15 \\
\hline 4. & $\begin{array}{l}\text { There is an alternative form of tourism places, such as pepper plantations agro, culinary } \\
\text { tours, horse riding and bird watching }\end{array}$ & 0.08 & 4 & 0.32 \\
\hline 5. & $\begin{array}{l}\text { The existence of Pelawan trees, honeybee, and Pelawan mushrooms which become an } \\
\text { icon and a hallmark attraction of Pelawan forest }\end{array}$ & 0.05 & 4 & 0.20 \\
\hline 6. & $\begin{array}{l}\text { The existence of tourism objects is not too far from the center of the capital city of } \\
\text { province, district, and airport }\end{array}$ & 0.05 & 3 & 0.15 \\
\hline \multicolumn{5}{|c|}{ Weaknesses } \\
\hline 1. & Lack of basic facilities and infrastructure in tourism places & 0.07 & 3 & 0.21 \\
\hline 2. & Limited professional tour guide & 0.06 & 2 & 0.12 \\
\hline 3. & Lack of information on the history and potential tourism place & 0.06 & 1 & 0.06 \\
\hline 4. & Ignoring environmental hygiene, especially the waste of food & 0.07 & 2 & 0.14 \\
\hline 5. & The existing supporting facilities in tourism place are in poorly maintained & 0.11 & 2 & 0.22 \\
\hline 6. & Lack of commitment and support from various sectors in developing tourism potential & 0.07 & 3 & 0.21 \\
\hline 7. & Lack of understanding in tourism development for sustainable development & 0.12 & 2 & 0.24 \\
\hline 8. & Lack of strategy in promoting and marketing the tourism place of Pelawan Forest & 0.08 & 2 & 0.16 \\
\hline Total & & 1 & - & 2.70 \\
\hline
\end{tabular}

\section{SWOT analysis}

Evaluation of the results of these internal factors such as local analysis which consists of strengths and weaknesses, while the analysis of external factors such as global analysis of opportunities and threats. Therefore, the need to create a matrix, swot analysis to determine SO, WO, ST, and WT. The four strategies are used in the SWOT analysis can be presented (Table 5) as follows:

a) SO: using internal strength to take the opportunities that exist outside.

b) WO: overcome internal weaknesses by taking opportunities from the outside.

c) ST: using internal strength to avoid the threats that exist outside.

d) WT: minimizing weaknesses and threats that may exist.

SWOT analysis also shows that the current situation of Pelawan Forest is worthy to serve in terms of potential ecotourism, conservation of natural resources and involving the local community in terms of management. The existence of this potential can certainly make an important contribution to society through the development of ecotourism that contributes directly to the improvement of the economy [12]. This suggests that the ecotourism of Pelawan Forest can be categorized as a sustainable tourism aims to enhance the benefits and minimize the effects of hazards through conservation, can be assessed using indicators of socio-cultural, community's economic income and environmental factors [13].

Tourism remains key sources of foreign exchange for one-third of developing countries and one-half of less developed countries and has significant potential as a driver for growth in the world economy. Furthermore, ecotourism and sustainable tourism, commonly referred to as "green tourism", carry the potential to increase employment directly; reduce poverty at the community level; improve efficiencies of water, energy, food supply, and waste ecosystem; and create locally production goods and services through cultural heritage and environmental conservation efforts [14].

Sustainable development is the most appropriate model for ecotourism. The variation of biodiversity provides an opportunity for visitors to enjoy these attractions besides offering rewards that benefit the local community. The stakeholders are not only economically profitable; their role as agents of conservation for environmental protection is also highlighted. The role of local communities and stakeholders is mutually beneficial which is seen as an economic concept of sustainability in increasing long-term economic business objectives and environmental stewardship. In reality, however, any infrastructure development can gradually erode the environmental resources [11]. From the SWOT analysis, it can be seen that 
there are four strategies that can be executed, namely market development strategy, horizontal integration strategy, product development strategy, and market penetrate strategy.

\section{Internal-external matrix}

Based on the value of internal factors (Table 3) amounted to 2.70 which indicated that strength is more than a threat, and the value of external factors (Table 4) of 3.11, which means more opportunities than threats. Therefore, a matrix of strategy position development of Pelawan Forest as an ecotourism object based on scores obtained from internal factors and external factors such as those occurring in (Fig. 2).

Table 4. EFAS (External Factor Analysis) Summary

\begin{tabular}{|c|c|c|c|c|}
\hline \multirow{3}{*}{ No. } & \multirow{2}{*}{ External Factors } & \multicolumn{3}{|c|}{ Value } \\
\hline & & Weight & Rating & Score \\
\hline & (1) & (2) & (3) & $(4 *)$ \\
\hline \multicolumn{5}{|c|}{ Opportunities } \\
\hline 1. & Creating jobs and providing direct benefits to the community & 0.08 & 4 & 0.32 \\
\hline \multirow{2}{*}{$\begin{array}{l}2 . \\
3 .\end{array}$} & The potential for research and education is very high & 0.07 & 4 & 0.28 \\
\hline & Conservation of Pelawan forest ecosystem is in an effort to reduce the negative impact & 0.06 & 4 & 0.24 \\
\hline 4. & The constant development of tourism so that it is increasing local revenue & 0.10 & 3 & 0.30 \\
\hline 5. & $\begin{array}{l}\text { It can attract tourists to exploit the potential of biological, history and social culture } \\
\text { resources }\end{array}$ & 0.07 & 3 & 0.21 \\
\hline 6. & $\begin{array}{l}\text { Eligibility in carrying out tourism plan is by taking into account environmental } \\
\text { requirements }\end{array}$ & 0.06 & 4 & 0.24 \\
\hline 7. & $\begin{array}{l}\text { The existence of the development of special economic zones of Bangka Belitung tourism } \\
\text { to attract number of tourists visit }\end{array}$ & 0.12 & 3 & 0.36 \\
\hline 8. & The geographical position is very strategic with the other tourist attractions to visit & 0.07 & 4 & 0.28 \\
\hline \multicolumn{5}{|c|}{ Threats } \\
\hline \multirow{2}{*}{$\begin{array}{l}1 . \\
2 .\end{array}$} & Lack of attention to the environmental impact of development projects attractions & 0.09 & 2 & 0.18 \\
\hline & The existence of mass tourism that damage the habitat of Pelawan forest flora and fauna & 0.17 & 2 & 0.34 \\
\hline 3. & $\begin{array}{l}\text { The situation is less favorable for the rating of if the icon/characteristic does not exist in } \\
\text { the time of their travel visit }\end{array}$ & 0.12 & 3 & 0.36 \\
\hline Total & & 1 & - & 3.11 \\
\hline
\end{tabular}

Source: Data analysis, 2017. Note: *) The results of the multiplication of the weights (2) and rating (3).

Table 5. Tourism Development Strategy based on SWOT Analysis

\section{SO strategy}

1. Development tourism by making an emphasis on ecotourism objects in promoting the quality of services and products that can be profitable

2. Developing the potential of ecotourism attractions by promoting local knowledge that is unique and distinctive local communities so that it attract tourists

3. Developing the concept of eco-tourism sustainably to attract tourists, students and researchers from various sciences

4. Using the potential of other areas to develop ecotourism in synergy

\section{ST Strategy}

1. In order to avoid the negative impacts of tourism on sensitive biodiversity, it is necessary to preserve the value of ecological planning development

2. Improving the facilities and buildings needed to attract number of tourists

3. Improving staff skill to monitor and protect forests, especially in enhancing conservation

4. Improving the information through tourism events and promote through electronic and printed media

5. Conducting an assessment of the environmental impacts of various development projects

\section{WO Strategy}

1. Providing a comprehensive tourism plan developed by the local government, organizations and other institutions related to the tourism industry

2. Communicating and introducing Pelawan forest attractions by using an educational package about the environment

3. Preparing travel packages that are run by corporate operators and travel with the collaboration of the government and local communities

4. Improving forest products of Pelawan forest with sustainable development based on local wisdom

\section{WT Strategy}

1. Creating a new alternative path for tourists in reducing build up in case there will be mass tourism

2. Conducting environmental education to reduce environmental impact

3. The development of infrastructure should be aligned with the increase of population caused by tourist visits

4. Placing professionals who are able to manage short-term and long-term plans related to ecotourism

Source: Data analysis, 2017. 
Total score of internal factors

\begin{tabular}{|c|c|c|c|}
\hline $\begin{array}{l}\text { Value } \\
\text { range }\end{array}$ & $\begin{array}{c}\text { High } \\
3.0-4.0\end{array}$ & $\begin{array}{l}\text { 'Moderate } \\
\text { II } 2.0-2.99\end{array}$ & $\begin{array}{c}\text { Low } \\
1.0-1.99\end{array}$ \\
\hline 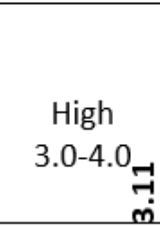 & 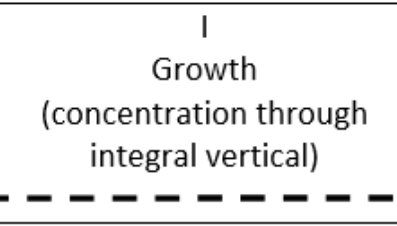 & $\begin{array}{l}\text { I Growth } \\
\text { (concentration through } \\
\text { integral horizontal) } \\
\text { _- I }\end{array}$ & $\begin{array}{c}\text { III } \\
\text { Shrinkage } \\
\text { (through turn down) }\end{array}$ \\
\hline $\begin{array}{c}\text { Moderate } \\
2.0-2.99\end{array}$ & $\begin{array}{c}\text { IV } \\
\text { Stability } \\
\text { (be careful) }\end{array}$ & $\begin{array}{c}\mathrm{V} \\
\text { Growth } \\
\text { (concentration through } \\
\text { integral horizontal) }\end{array}$ & $\begin{array}{c}\text { VI } \\
\text { Shrinkage }\end{array}$ \\
\hline $\begin{array}{c}\text { Low } \\
1.0-1.99\end{array}$ & $\begin{array}{c}\text { VII } \\
\text { Growth } \\
\text { (concentric diversification) }\end{array}$ & $\begin{array}{c}\text { VIII } \\
\text { Growth } \\
\text { (concentric diversification) }\end{array}$ & $\begin{array}{c}\text { XI } \\
\text { Shrinkage } \\
\text { (liquidation or bankrupt) }\end{array}$ \\
\hline
\end{tabular}

Figure 2. Matrix of Internal Factors and External Factors

The criteria matrix of internal factors and external factors are included in the first category, which is located in the second quadrant (growth areas). This indicates that the tourism object is included in the second quadrant which can be described as the growing and build, meaning Pelawan Forest is strong enough and has the competence for development as an object of ecotourism, but the current market opportunity is also very threatening the environmental damage from ecotourism object development if not prioritizing conservation efforts.

\section{Grand strategy matrix}

Grand strategy matrix is the tool for formulate alternative strategies which based on two evaluative dimensions: competitive position and market growth. Appropriate strategies for an organization to consider are listed in sequential order of attractiveness in each quadrant of the matrix. Based on the internal factors and external factors which are known from formulation strategy stage, the Pelawan Forest Grand Strategy Matrix is in quadrant II (Fig. 3).

The matrix above shows that develop of Pelawan Forest in quadrant two of the Grand Strategy Matrix is characterized with a weak competitive position in fast growing market. The Pelawan Forest needs to evaluate for identify the gray areas of incompetence and the reasons behind such ineffectiveness. Moreover, adoption of counteractive measures is also indispensable so that ability to compete effectively strengthens and the firm can find its space in the more competitive environment. Because in quadrant two are in a rapid market growth industry, therefore, an intensive strategy, more appropriately, can be classified as the first option to adopt

In a case of the quadrant II does not find any suitable strategy to adopt than divestiture of some divisions can be considered as another option. Such an arrangement may avail the desired funding to invest in the current venture in other divisions to strengthen the competitive position. Moreover, as last resort, liquidation should be considered so that another business can be acquired.

After performing the analysis and knowing the alternative strategies that emerged in the analysis phase through three kinds of techniques, namely SWOT analysis, internal-external matrix and Grand strategy matrix. Pelawan Forest is very appropriate to be a place for ecotourism destination because it has its own characteristics and advantages which are not found in other attractions. So it must be managed in accordance with the principles of sustainable development. The strategies which are needed to support these efforts can be carried out by forming responsible behavior towards environmental conservation. Responsible behavior is not only to the managers but can be maximized if the tourists can also help in order to minimize damage to the environment 
[15]. In the context of ecotourism, the environmentally responsible behavior is given when tourists understand the impact of their behavior on the environment and abide by the norms in the ecologic side [16].

Travelers give the opinion about the need for more detail promotional activities about the potential attraction, along with how to enable and enhance the information in the cottage area of Biodiversity Park of Pelawan Forest to tourists who visit as well as the need to increase tourist guide services. So, in order to support the efforts, it is needed for collaboration of each party, the local communities, and governments to build a network in encouraging sustainable tourism development [17].

This research presents ecotourism of Pelawan Forest by using SWOT analysis, internal-external matrix, and Grand strategy matrix. This analysis is useful to identify the factors positively and negatively affecting the development of sustainable ecotourism in Pelawan Forest and support aggressive strategies. Based on its potential, the priority of ecotourism development strategy can be through the efforts:

a) coordination between local communities and stakeholders in the ecotourism development of Pelawan Forest;

b) rearrangement of space for ecotourism activities, improvement of infrastructure and supporting units of tourist needs;

c) giving knowledge to the community on the management and training of effective and productive ecotourism management;

d) conduct a study on the impact of tourism impact on environmental conditions with regular monitoring and sustainable

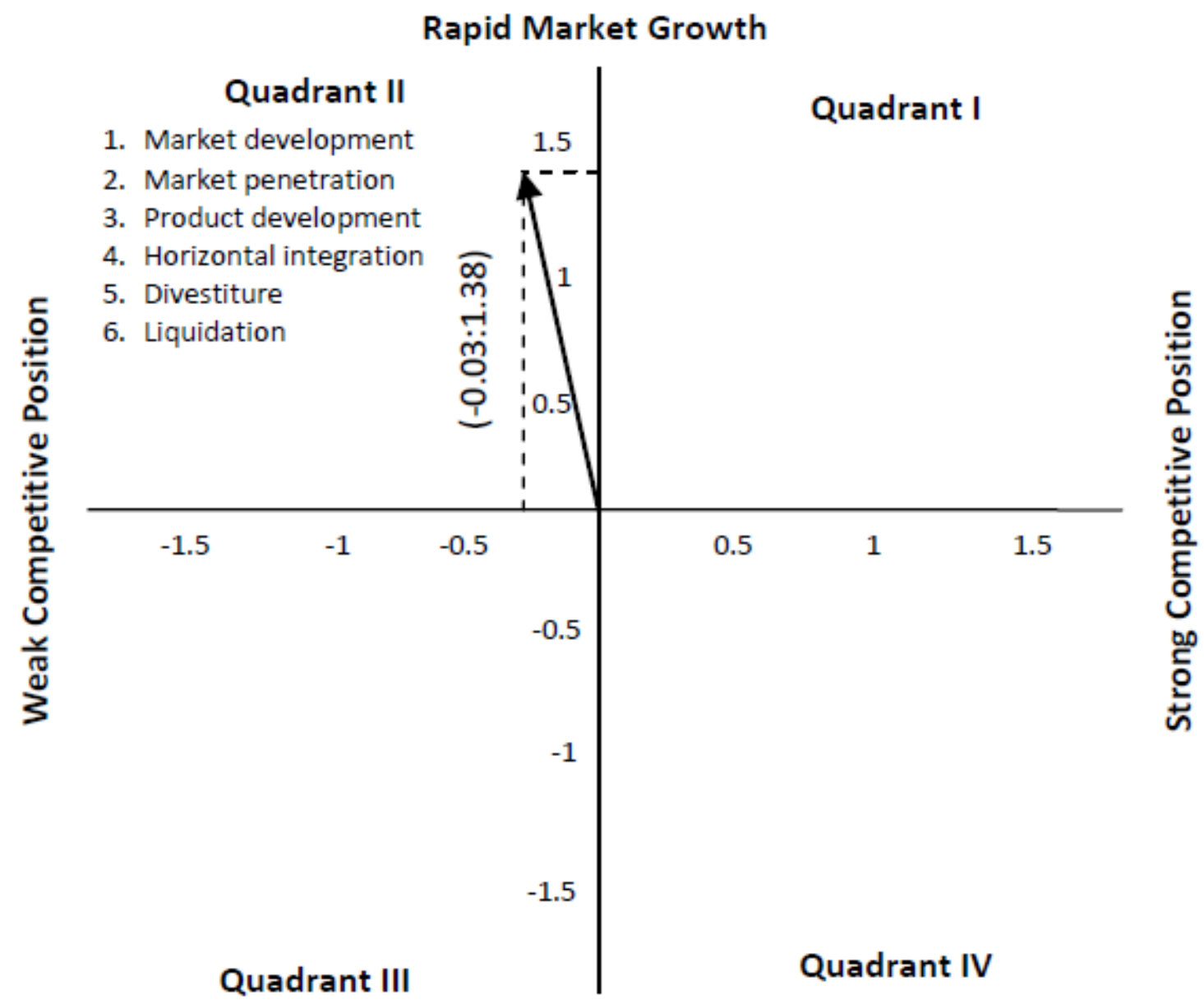

\section{Slow Market Growth}

Figure 3. Grand strategy matrix ecotourism development of Pelawan Forest 


\section{CONCLUSION}

The main strength of the Pelawan forest ecotourism lies in the sustainable conservation of natural resources, the diversity of major tourist attractions as well as alternative tourism and the involvement of communities in supporting environmental conservation efforts, so it can be an opportunity to create jobs and provide direct economic benefits. Based on the analysis that has been done that ecotourism of Pelawan Forest is strong enough and has competence for development, but the current market opportunity is also very threatening the occurrence of the forest environment damage. Therefore, need to seriously evaluate their approach to the market. Although their industry is growing, they are not able to compete effectively, and they need to figure out why the company's approach is not currently effective and how companies find out why the company's current approach is ineffective and how it improves its competitiveness. For this purpose intensive strategy can be used as the primary choice to consider. But if it lacks a competitive advantage, horizontal integration becomes another good alternative. As a last resort, divestiture or liquidation may be considered.

\section{REFERENCES}

[1] Statistics of Bangka Belitung Island Province. 2016. Bangka Belitung Island Province in figures. Statistics of Bangka Belitung Island Province. Pangkalpinang.

[2] Budowski, G. 1976. Tourism and environmental conservation: Conflict, coexistence, or symbiosis? Environmental Conservation 3(1), 27-31.

[3] Hall, C. M., M. James and T. Baird. 2011. Forests and trees as charismatic megaflora: implications for heritage tourism and conservation. Journal of Heritage Tourism 6(4), 309-323.

[4] Shackleton, S., B. Campbell, E. Wollenberg and E. Edmunds. 2002. Devolution and community-based natural resource management: Creating space for local people to participate and benefit?. Natural Resource Perspectives 76, 1-6.

[5] Kuvan, Y. and P. Akan. 2005. Residents attitudes toward general and forest-related impacts of tourism: The case of Belek, Antalya. Tourism Management 26(5), 691706.

[6] Dudley, N. 2008. Guidelines for applying protected area management categories.
Gland, Switzerland. IUCN (The International Union for Conservation of Nature). Available: https://books.google.co.uk.

[7] Reihanian, A., N. Z. B. Mahmood, E. Kahrom and T. W. Hin. 2012. Sustainable tourism development strategy by SWOT analysis: Boujagh National Park, Iran. Tourism Management Perspectives 4, 223-228.

[8] Siswanto A. and Moeljadi. 2015. Ecotourism development strategy Baluran National Park in the Regency of Situbondo, East Java, Indonesia. International Journal of Evaluation and Research in Education 4(4), 185-195.

[9] Sayyed, M. R. G., M. S. Mansoori and R. G. Jaybhaye. 2013. SWOT analysis of Tandooreh National Park (NE Iran) for sustainable ecotourism. In Proceedings of the International Academy of Ecology and Environmental Sciences 3, 296-305.

[10] Batabyal A. A. 2016. Accessibility, vulnerability, and resilience in a stochastic model of sustainable ecotourism. Transportation Research Part D: Transport and Environment 43, 71-81.

[11] Sánchez, C. I. and M. E. Jaramillo-Hurtado. 2010. Policies for enhancing sustainability and competitiveness in tourism in Colombia. Worldwide Hospitality and Tourism Themes 2(2), 153-162.

[12] Adamu, A., M. R. Yacob, A. Radam, R. Hashim and S. U. Adam. 2015. Economic valuation of ecotourism resources in Yankari Game Reserve, Bauchi Nigeria. Procedia Environmental Sciences 30, 139144.

[13] Lozano-Oyola, M., F. J. Blancas, M. González and R. Caballero. 2012. Sustainable tourism indicators as planning tools in cultural destinations. Ecological Indicators 18, 659675.

[14] UNEP (United Nations Environment Programme). 2011. Tourism: Investing in energy and resource efficiency. In: Towards a green economy: pathways to sustainable development and poverty eradication. Sustainable Development. Available. www.unep.org.

[15] Lee, T. H. 2011. How recreation involvement, place attachment and conservation commitment affect environmentally responsible behavior. Journal of Sustainable Tourism 19(7), 895915.

[16] Puhakka, R. 2011. Environmental concern 
and responsibility among nature tourists in Oulanka PAN Park, Finland. Scandinavian Journal of Hospitality and Tourism 11(1), 76-96.

[17] Arnaboldi, M. and N. Spiller. 2011. Actornetwork theory and stakeholder collaboration: The case of Cultural Districts. Tourism Management 32(3), 641-654. 